\title{
Exocrine Pancreatic Cancer TNM Finding v8
}

National Cancer Institute

\section{Source}

National Cancer Institute. Exocrine Pancreatic Cancer TNM Finding v8. NCI Thesaurus.

Code C134877.

A finding about one or more characteristics of exocrine pancreatic cancer, following the rules of the TNM AJCC V8 classification system. This classification applies to pancreatic ductal adenocarcinoma, acinar cell carcinoma, intraductal papillary mucinous neoplasm with associated invasive carcinoma, intraductal tubulopapillary neoplasm with associated invasive carcinoma, colloid carcinoma, mucinous cystic neoplasm with associated invasive carcinoma, solid pseudopapillary neoplasm, large cell neuroendocrine carcinoma, small cell neuroendocrine carcinoma, and pancreatoblastoma. Well-differentiated neuroendocrine tumors are not staged using this staging system. (from AJCC 8th Ed.) 